\title{
Capital Structure Evaluation Based Company Sizes And Profitability
}

\author{
${ }^{1 *}$ Aprih Santoso, ${ }^{2}$ Sri Yuni Widowati, ${ }^{3}$ Emaya Kurniawati \\ ${ }^{1,2,3}$ Fakultas Ekonomi Universitas Semarang (USM), Indonesia \\ *Email korenpondensi: aprihsantoso@usm.ac.id
}

\begin{abstract}
The purpose of this study is to evaluate the effect of : (1) Firm Size on Profitability (ROA). (2) Firm Size on Capital Structure (DER). (3) Profitability (ROA) on Capital Structure (DER) in the Manufacturing Sector Automotive Companies and Components on the IDX. The data used are secondary data using a sample of 13 automotive sector manufacturing companies and components listed on the Indonesia Stock Exchange in 20162018. Sampling was done using a sensus method. This research uses a quantitative approach and the analysis technique used is multiple linear regression analysis (path analysis.The results of this study are: (1) FirmSize significantly has a positive effect on profitability (ROA). (2) Firm Size significantly has a positive effect on capital structure (DER). (3) Profitability (ROA) significantly has a positive effect on capital structure (DER).
\end{abstract}

Keywords: Capital Structure, Firm Size, Profitability.

Saran sitasi: Santoso, A., Widowati, S. Y., \& Kurniawati, E. (2020). Capital Structure Evaluation Based Company Sizes And Profitability. Jurnal Akuntansi dan Pajak, 20(2), 205-211. doi: http://dx.doi.org/10.29040/jap.v20i2.765

DOI: http://dx.doi.org/10.29040/jap.v20i2.765

\section{Pendahuluan}

Struktur Modal (capital structure) merupakan kombinasi hutang dan ekuitas dalam struktur keuangan jangka panjang perusahaan, atau dalam arti lain pertimbangan antara penggunaan pinjaman berjangka dengan penggunaan modal sendiri, artinya berapa jumlah modal dan berapa jumlah hutang yang digunakan agar modal bisa optimal (Armelia, 2016). Dengan adanya struktur modal yang optimal, maka perusahaan akan mendapatkan hasil dengan tingkat yang optimal juga, sehingga perusahaan dan pemegang saham mendapatkan keuntungan. Debt to Equity Ratio, merupakan rasio dalam struktur modal yang digunakan untuk menilai utang dengan ekuitas (Hudan, et al., 2016). Rasio ini berguna untuk mengetahui jumlah utang dibandingkan dengan modal yang dimiliki perusahaan. Dengan kata lain, rasio ini untuk mengetahui setiap rupiah modal sendiri yang dijadikan untuk jaminan utang. Dalam kondisi DER diatas 1 perusahaan harus menanggung utang yang lebih besar dibandingkan modal yang dimiliki, resiko yang ditanggung perusahaan juga meningkat.
Investor cenderung lebih tertarik pada tingkat Debt to EquityRatio tertentu yang besarnya kurang dari 1, karena jika lebih besar dari 1 menunjukkan resiko yang dimiliki perusahaan semakin tinggi.Dengan mengetahui apa dan bagaimana faktor-faktor yang paling mempengaruhi struktur modal perusahaan industri yang terdaftar di Bursa Efek Indonesia akan dapat membantu khususnya pihak manajemen perusahaan yang ada dalam perusahaan tersebut dalam menentukan bagaimana seharusnya pemenuhan kebutuhan dana untuk mencapai struktur modal yang optimal harus dilakukan dan juga para investor di pasar modal umumnya. Ada beberapa faktor yang dapat mempengaruhi struktur modal perusahaan, seperti misalnya : profitabilitas dan ukuran perusahaan.

Ukuran perusahaan menggambarkan besar kecilnya suatu perusahaan dimana perusahaan yang besar yang akan lebih muda mendapatkan pinjaman dari pihak luar baik dalam bentuk utang maupun modal saham karena biasanya perusahaan besar disertai dengan reputasi yang cukup baik dimata masyarakat \{Lasut, Rate, \& Raintung, 2018). 
Ukuran perusahaan dapat diartikan sebagai besar kecilnya perusahaan dilihat dari besarnya nilai equity, nilai perusahaan, ataupun hasil nilai aktiva dari suatu perusahaan (Armelia, 2016). Berikut beberapa hasil penelitian terdahulu yang membahas tentang struktur modal.

\section{Tabel 1}

Riset Gap Hasil penelitian Terdahulu tentang Struktur Modal

\begin{tabular}{lc}
\hline \multicolumn{1}{c}{ Peneliti } & Ukuran Perusahaan \\
\hline Yudi,D. P dan Rusmalia, & Berpengaruh Positif \\
M (2016) & Tidak Berpengaruh \\
Armelia, S. (2016) &
\end{tabular}

Dari tabel di atas menunjukan bahwa terjadi perbedaan hasil penelitian. Berdasarkan pemikiran riset gap diatas, maka untuk memecahkan permasalahan perbedaan hasil penelitian terdahulu antara ukuran perusahaan terhadap struktur modal maka perlu diselesaikan dengan memasukkan variabel profitabilitas sebagai variabel mediasi. Sebagaimana diketahui profitabilitas adalah kemampuan perusahaan mendapatkan laba melalui semua kemampuan dan sumber yang ada seperti : penjualan, kas, modal, jumlah karyawan, jumlah cabang, dan sebagainya. Berdasarkan latar belakang di atas, maka dapat dirumuskan permasalahannya adalah bagaimana pengaruh ukuran perusahaan dan profitabilitas terhadap struktur modal, bagaimana pengaruh ukuran perusahaan terhadap profitabilitas. Tujuan penelitian ini adalah menganalisis pengaruh ukuran perusahaan dan profitabilitas terhadap struktur modal, dan pengaruh ukuran perusahaan terhadap profitabilitas.

\section{Teori Struktur Modal}

Struktur Modal menurut Anggriyani (2016), adalah perimbangan atau perbandingan antara modal asing (jangka panjang) dengan modal sendiri. Brigham dan Houston (2011) menyatakan bahwa terdapat empat faktor yang mempengaruhi keputusan struktur modal: (a) Risiko usaha, atau tingkat risiko yang inheren dalam operasi perusahaan jika perusahaan tidak menggunakan utang. Makin besar risiko usaha perusahaan, makin rendah rasio utang optimalnya. (b) Posisi pajak perusahaan. Salah satu alasan utama digunakannya utang karena bunga merupakan pengurang pajak, selanjutnya menurunkan biaya utang efektif. Akan tetapi, jika sebagian besar laba suatu perusahaan telah dilindungi dari pajak oleh perlindungan pajak yang berasal dari penyusutan, maka bunga atas utang yang saat ini belum dilunasi, atau kerugian pajak yang dibawa ke periode berikutnya akan menghasilkan tarif pajak yang rendah.

Akibatnya, tambahan utang tidak akan memberikan keunggulan yang sama jika dibandingkan dengan perusahaan yang memiliki tarif pajak efektif yang lebih tinggi.(c) Fleksibilitas keuangan, atau kemampuan untuk menghimpun modal dengan persyaratan yang wajar dalam kondisi yang buruk. Pasokan modal yang lancar akan memengaruhi operasional perusahaan yang selanjutnya memiliki arti sangat penting bagi keberhasilan jangka panjang, dan (d) Konservatisme atau keagresifan manajerial. Beberapa manajer lebih agresif dibandingkan manajer yang lain, sehingga manajer lebih bersedia menggunakan utang sebagi usaha untuk meningkatkan laba. Faktor ini tidak memengaruhi struktur modal optimal yang sebenarnya, atau struktur modal yan memaksimalkan nilai, tetapi akan berpengaruh terhadap sasaran struktur modal perusahaan.

Salah satu rasio dalam struktur modal yang akan digunakan dalam penelitian ini adalah Debt to Equity Ratio (DER), yaitu rasio yang mengukur jumlah hutang atau dana dari luar perusahaan terhadap modal sendiri (shareholders equity) (Raharjaputra, 2006).

\section{Teori Ukuran Perusahaan (Firm Size)}

Wimelda dan Marlinah (2013) menyatakan bahwa ukuran perusahaan mengambarkan besar kecilnya suatu perusahaan dimana perusahaan yang besar akan lebih mudah mendapatkan pinjaman dari luar baik dalam bentuk utang maupun modal saham karena biasanya perusahaan besar disertai dengan reputasi yang cukup baik dimata masyarakat. Ukuran perusahaan yang besar, dianggap sebagai suatu indikator yang menggambarkan tingkat risiko bagi investor untuk melakukan investasi pada perusahaan tersebut, karena jika perusahaan memiliki kemampuan finansial yang baik, maka diyakini bahwa perusahaan tersebut juga mampu memenuhi segala kewajiban serta memberikan tingkat pengembalian yang memadai bagi investor (Joni \& Lina, 2010). Semakin besar ukuran sebuah perusahaan, maka semakin besar modal yang dibutuhkan perusahaan tersebut untuk operasionalnya, semakin besar total aset yang dimiliki perusahaan, dan semakin besar pula kecenderungan penggunaan akan dana eksternal. Ukuran Perusahaan (firm size) mengindikasikan bahwa semakin besar suatu perusahaan semakin besar pula tingkat utangnya. Perusahaan yang lebih 
besar dimana sahamnya tersebar sangat luas akan lebih berani mengeluarkan saham barudalam memenuhi kebutuhannya untuk membiayai pertumbuhan penjualannya dibanding perusahaan yang lebih kecil.

Semakin besar ukuran perusahaan, kecenderungan memakai dana eksternal juga semakin besar. Dalam penelitian ini, pengukuran terhadap ukuran perusahaan dengan nilai logaritma natural dari total aset (natural logarithma of asset).

Rumus logaritma naturan dari total aset.

\section{Teori Profitabilitas (Return On Assets/ ROA)}

Rasio profitabilitas (profitability ratio) mencerminkan hasil akhir dari seluruh kebijakan keuangan dan keputusan operasional. ROA merupakan rasio yang akan dipakai dalam penelitian ini sebagai proksi dari rasio profitabilitas. ROA merupakan rasio laba bersih terhadap total aset akan mengukur pengembalian atas total aset (retun on total asset -ROA) setelah bunga dan pajak.Tingkat pengembalian atas aset yang rendah tidak selalu berarti buruk itu dapat diakibatkan oleh keputusan yang disengaja untuk menggunakan utang dalam jumlah besar, beban bunga yang tinggi menyebabkan laba bersih menjadi relatif rendah. Melihat situasi secara keseluruhan ketika menilai kinerja suatu perusahaan dan mencoba untuk memikirkan apa yang harus dilakukan untuk memperbaiki situasi itulah yang baik dilakukan.

\section{Pengaruh Ukuran Perusahaan Terhadap Profitabilitas}

Ukuran atau size dari sebuah perusahaan dapat juga dilihat dari beberapa hal, seperti struktur organisasi,jumlah karyawan, aset perusahaan, dan jumlah saham yang beredar. Menurut teori critical, semakin besar skala perusahaan maka profitabilitas juga akan meningkat, karena dengan adanya sumber daya yang besar, maka perusahaan dapat melakukan investasi baik untuk aktiva lancar maupun aktiva tetap dan juga memenuhi permintaan produk. Hasil penelitian yang dilakukan oleh (Ambarwati, Yuniarta, \& Sinarwati, 2015) dan Barus \& Leliani (2013)yang menunjukkan bahwa ukuran perusahaan berpengaruh terhadap profitabilitas perusahaan. Hipotesis dalam penelitian ini adalah :

$\mathrm{H}_{1}$ : Ukuran Perusahaan berpengaruh terhadap Profitabilitas

\section{Pengaruh Profitabilitas Tehadap Struktur Modal}

Profitabilitas adalah pengembalian atas investasi modal. Perusahaan dengan rate of retrun yang tinggi cendereung menggunakan proporsi utang yang relatif kecil. Karena dengan rate of retrun yang tinggi, kebutuhan dana dapat diperoleh dari laba ditahan. Perusahaan dengan profitabilitas tinggi akan lebih banyak mempunyai dana internal dari pada perusahaan yang profitabilitasnya rendah. Profitabilitas berpengaruh pada struktur modal (Andayani \& Suardana (2018), Sari \& Haryanto (2013), Joni \& Lina (2010) dan Armelia (2016), Dewiningrat \& Mustanda (2018). Primantara \& Dewi (2016). Hipotesis dalam penelitian ini adalah :

$\mathrm{H}_{2}$ : Profitabilitas berpengaruh terhadap Struktur Modal

\section{Pengaruh Ukuran Perusahaan Terhadap Struktur Modal}

Ukuran perusahaan menggambarkan besar kecilnya suatu perusahaan, besar kecilnya perusahaan dapat ditinjau dari lapangan usaha yang dijalankan. Penentuan besar kecilnya skala perusahaan dapat ditentukan berdasarkan total penjualan, total aktiva, rata-rata tingkat penjualan, dan rata-rata total aktiva. Perusahaan yang lebih besar akan lebih mudah memperoleh pinjaman dibandingkan perusahaan kecil, Oleh karena itu dapat memungkinkan untuk perusahaan besar, tingkat leveragenya akan lebih besar dari perusahaan yang berukuran kecil. Dapat disimpulkan bahwa ukuran perusahaan akan berpengaruh terhadap struktur modal dengan didasarkan pada kenyataan bahwa semakin besar suatu perusahaan, ada kecenderungan untuk menggunakan jumlah pinjaman yang lebih besar. Ukuran perusahaan berpengaruh pada struktur modal (Primantara \& Dewi, 2016, Alvareza dan Topowijono, 2017 dan Sari \& Haryanto, 2013). Hipotesis dalam penelitian ini adalah :

$\mathrm{H}_{3}$ : Ukuran Perusahaan berpengaruh terhadap Struktur Modal

\section{Model Penelitian}

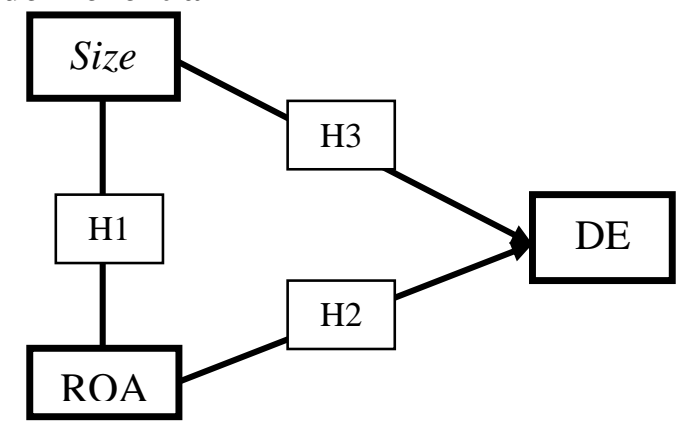

Gambar1.

Model Penelitian 


\section{Metode Penelitian \\ Obyek Penelitian \\ Data yang digunakan adalah data sekunder dengan menggunakan sampel sebanyak 13 perusahaan manufaktur sektor otomotif dan komponen yang terdaftar di Bursa Efek Indonesia pada tahun 2016-2018. Obyek penelitian adalah perusahaan manufaktur sektor otomotif dan komponen yang terdaftar di Bursa Efek Indonesia pada tahun 2016-2018.}

\section{Populasi dan Prosedur Penentuan Sampel}

Populasi dalam penelitian ini adalah perusahaan manufaktur sektor otomotif dan komponen yang terdaftar di Bursa Efek Indonesia pada tahun 20162018. Adapun pemilihan sampel berdasarkan sensus sehingga data sampel yang diolah sebanyak 39 perusahaan (13 perusahaan $\mathrm{x} 3$ periode penelitian). Penelitian ini menggunakan pendekatan kuantitatif dan teknik analisis yang digunakan adalah analissis regresi linier berganda (path analysis).

\section{Uji Normalitas}

Uji normalitas dalam penelitian ini juga dilihat dari rasio kolmogorov smirnov (KS), jika rasio KS diatas 0,05 , maka data terdistribusi normal.

\section{Uji Multikolinearitas}

Uji ini bertujuan menguji apakah pada model regresi ditemukan adanya korelasi antar variabel independen. Pada model regresi yang baik seharusnya antar variabel independen tidak terjadi kolerasi. Untuk mendeteksi ada tidaknya multikoliniearitas dalam model regresi dapat dilihat dari tolerance value atau variance inflation factor (VIF). Untuk mendeteksi ada atau tidaknya multikoliniearitas didalam model ini dilihat dari nilai VIF dan Tolerance. Nilai cut off Tolerance $<0.10$ dan VIF $>10$ (berarti terdapat multikolinearitas).

\section{Uji Heteroskedastisitas}

Uji heterokedastisitas bertujuan untuk menguji apakah dalam model regresi terjadi ketidaksamaan variance dari residual satu pengamatan ke pengamatan yang lain. Penelitian ini juga dilakukan uji gleyser, nilai signifikansi > 0,05 maka tidak terjadi heteroskedastisitas atau dengan kata laintidak ada pengaruh variabel independen terhadap residualnya..

\section{Uji Autokorelasi}

Uji autokorelasi bertujuan untuk menguji apakah dalam suatu model regresi linear ada korelasi antara kesalahan pengganggu pada periode sekarang dengan kesalahan pada periode sebelumnya. Uji ini menggunakan Uji Durbin Watson untuk melihat ada tidaknya autokorelasi.

Pedoman

penarikan

kesimpulan ada tidaknya autokorelasi dengan $U j i$

Durbin Watson didasarkan pada hasil perhitungan yang terdapat dalam tabel berikut:

Tabel 3 Autokolerasi

\begin{tabular}{llr}
\hline \multicolumn{1}{c}{ Hasil Perhitungan } & \multicolumn{2}{c}{ Kesimpulan } \\
\hline Kurang dari 1,08 & Ada gejala \\
& autokorelasi \\
1,08 sampai dengan 1,76 & \multicolumn{2}{l}{ Tidak ada kesimpulan } \\
1,76 sampai dengan 2,24 & Tidak ada gejala \\
& autokorelasi \\
2,24 sampai dengan 2,92 & Tidak ada kesimpulan \\
Lebih dari 2,92 & Ada gejala \\
& autokorelasi \\
\end{tabular}

\section{Koefisien Determinasi (Uji $\mathbf{R}^{2)}$}

Koefisien determinasi (R2) digunakan untuk mengukur seberapa jauh kemampuan model dalam menerangkan variasi variabel dependen. Nilai koefisien determinasi adalah antara 0 dan 1 . Nilai $\mathrm{R}^{2}$ yang kecil berarti kemampuan variabel-variabel independen dalam menjelaskan variasi variabel dependen amat terbatas.

\section{Uji F}

Pengujian terhadap koefisien regresi dilakukan dengan uji F. Pengujian ini dilakukan untuk menguji kelayakan model. Tingkat signifikansi sebesar 5\% nilai $\mathrm{F}$ ratio dari masing-masing koefisien regresi kemudian dibandingkan dengan niai $\mathrm{t}$ tabel. Jika Frasio > Ftabel atau prob-sig $<\mathrm{a}<0,05$ berarti bahwa model layak untuk digunakan (goodness of fit).

\section{Pengujian Hipotesis}

Pengujian terhadap koefisien regeresi secara parsial dilakukan dengan uji t. Pengujian ini dilakukan untuk mengetahui signifikansi peran secara parsial antara variabel independen terhadap variabel dependen dengan mengasumsikan bahwa variabel independen lain dianggap konstan. Tingkat signifikansi sebesar 5\%, nilai t hitung dari masingmasing koefisien regresi kemudian dibandingkan dengan nilai t tabel. Jika t-hitung $>\mathrm{t}$-tabel atau prob$\operatorname{sig}<\alpha=5 \%$, maka hipotesis diterima berarti bahwa masing-masing variabel independen berpengaruh secara positif terhadap variabel dependen.

\section{Hasil Penelitian dan Pembahasan Deskripsi Variabel Penelitian}

Pengujian ini dilakukan untuk mempermudah memahami variabel-variabel yang digunakan dalam penelitian. Data yang diolah sebanyak 39 data, yang 
didapat dari 13 sampel perusahaan dikali 3 periode penelitian yaitu dari tahun 2016 hingga 2018. Ulasan mengenai deskriptif statistik setiap variabel dapat dijelaskan sebagai berikut :

a. Pada variabel ukuran peusahaan memiliki nilai minimum 0,42 dan nilai maksimum 62,04 serta nilai standart deviasi sebesar 3,9656.

b. Pada variabel profitabilitas dengan proksi ROA memiliki nilai minimum 0,26 dan nilai maksimum 23,60 serta nilai standar deviasi sebesar 4,0625.

c. Pada variabel struktur modal dengan proksi DER memiliki nilai minimum 0,33 dan nilai maksimum 5,22 serta nilai standart deviasi sebesar 3,1302.

\section{Uji Normalitas}

Pengujian terhadap normalitas data dilakukan dengan menggunakan uji statistic (KolmogorovSmirnov). Penyajian uji normalitas dapat dilihat sebagai berikut : hasil uji normalitas dapat diketahui nilai asyim sig variabel ukuran perusahaan $($ SIZE $)=$ 0,093 variabel profitabilitas $(\mathrm{ROA})=0,075$, dan struktur modal $(\mathrm{DER})=0,134$. Dengan demikian dapat disimpulkan bahwa data pada penelitian ini data berdistribusi dengan normal karena keseluruhan variabel nilai signifikansinya lebih besar dari 0,05.

\section{Uji Multikolinearitas}

Uji multikolonieritas bertujuan untuk menguji apakah model regresi ditemukan adanya korelasi antar variabel bebas (independen), yang dapat diketahui melalui Variance Inflation Factor (VIF) dan tolerance. Hasil uji antar variabel independenya yaitu ukuran perusahaan (SIZE) dengan tolerance $(0,267)$ dan VIF $(3,630)$; dan untuk variabel profitabilitas (ROA) dengan tolerance $(0,151)$ dan VIF $(1,102)$ sehingga tidak terjadi multikolonieritas karena untuk variabel ukuran perusahaan (SIZE) dan variabel profitabilitas (ROA) hasil perhitungannya tolerance $>0,1$ dan nilai VIF $<10$, sehingga dapat dikatakan tidak terjadi gejala multikolinieritas.

\section{Uji Autokorelasi}

Uji autokorelasi dilakukan dengan menggunakan uji Runs Test. Runs test digunakan untuk melihat apakah data residual terjadi secara tidak (sistematis). Hasil uji runs test menunjukan nilai asyim sig sebesar 0,257>0,05 yang berarti Ho ditolak, sehingga dapat disimpulkan bahwa residual tidak terjadi autokorelasi antar nilai residual.

\section{Uji Heteroskedastisitas}

Untuk menentukan heteroskedastisitas juga dapat menggunakan uji glejser.Hasil uji glejser menunjukan bahwa ukuran perusahaan (SIZE) memiliki nilai sig. sebesar $0,651>0,05$ dan variabel profitbilitas (ROA) sebesar 0,3273>0,05. Jadi dapat disimpulkan tidak adanya gejala heteroskedastisitas.

\section{Analisis Regresi Linier}

Hasil dari pengujian asumsi klasik menunjukan data data berdistribusi normal, tidak terdapat multikoloniaritas, autokorelasi dan heterokedastisitas, maka langkah selanjutnya adalah analisis regresi linier:

\section{a) Analisis Regresi Sederhana}

Hasil analisis regresi linier sederhana dapat dilihat coefisient byang merupakan hasil dari analisis regresi sederhana dengan persamaan sebagai berikut:

\section{Prof. $($ ROA $)=$ 7,254+0,591UP $($ SIZE)}

Dari persamaan regresi linier sederhana diatas maka dapat diintepretasikan sebagai berikut: koefisien regresi variabel ukuran perusahaan (SIZE) sebesar 0,591 (positif), yang artinya semakin besar ukuran perusahaan, maka semakin meningkat profitabilitasnya (ROA).

\section{b) Analisis Regresi Linear Berganda}

Hasil analisis regresi linier berganda yang dilihat pada coefisient $b$ merupakan hasil dari analisis regresi dengan persamaan sebagai berikut:

$$
\mathrm{SM}(\mathrm{DER})=4.527+0,633 \mathrm{UP}(\text { SIZE })+0.857 \text { Prof. }
$$

\section{(ROA)}

Dari persamaan regresi linier berganda maka dapat diintepretasikan sebagai berikut:

a. Koefisien regresi variabel ukuran perusahaan (SIZE) sebesar 0,633 (positif), yang artinya semakin tinggi profitabilitas, maka semakin meningkat struktur modal (DER).

b. Koefisien regresi variabel profitabilitas (ROA) sebesar 0,857 (positif), yang artinya semakin tinggi profitabilitas (ROA), maka semakin meningkat struktur modalnya (DER)

\section{Uji Signifikansi Parameter Individual (Uji Statistik t)}

a. Pengujian Hipotesis (H1)

Berdasarkan tabel pengujian hipotesis mengenai pengaruh ukuran perusahaan (SIZE) terhadap profitabilitas (ROA) menunjukkan bahwa nilai signifikan sebesar $0,000<0,05$ dengan arah koefisien positif, maka dapat disimpulkan ukuran perusahaan (SIZE) berpengaruh positif dan signifikan terhadap profitabilitas (ROA). Maka hipotesis 1 diterima. Hal ini menjelaskan bahwa semakin besar perusahaan menandakan semakin 
besar pula return dari pada modal investor, yang mana hal tersebut tentu akan lebih membuat investor tertarik untuk menanamkan modalnya di perusahaan tersebut. Ukuran perusahaan berpengaruh terhadap profitabilitas (Ambarwati, Yuniarta, \& Sinarwati, 2015) dan Barus \& Leliani (2013). Hal ini menandakan bahwa ukuran perusahaan yang besar menunjukkan prospek perusahaan yang baik. Hal tersebut dapat dipahami karena perusahaan yang semakin besar berhasil, mengindikasikan perusahaan tersebut mempunyai kinerja yang baik, sehingga dapat menciptakan sentimen positif para investor. Hasil penelitian ini tidak mendukung hasil penelitian yang dilakukan oleh Sari \& Haryanto (2013), Armelia (2016) yang meyatakan bahwa ukuran perusahaan tidak berpengaruh secara signifikan terhadap profitabilitas.

b. Pengujian Hipotesis (H2)

Berdasarkan tabel pengujian hipotesis mengenai pengaruh profitabilitas (ROA) terhadap struktur modal (DER) menunjukkan bahwa nilai signifikan sebesar $0,000<0,05$ dengan arah koefisien positif, maka dapat disimpulkan profitabilitas (ROA) berpengaruh positif dan signifikan terhadap struktur modal (DER). Maka hipotesis 2 diterima. Hasil penelitian ini mendukung penelitian yang dilakukan oleh Andayani \& Suardana (2018), Dewiningrat \& Mustanda (2018), Joni \& Lina (2010), Primantara \& Dewi (2016), Sari \& Haryanto (2013) dan Armelia (2016).

Hasil penelitian ini bertentangan dengan hasil penelitian yang dilakukan Lasut, Rate, \& Raintung (2018), dan Akhmadi, Rosyid, \& Handayani (2018) yang menyatakan bahwa profitabilitas tidak berpengaruh terhadap struktur modal. Hasil ini sesuai dengan pecking order theory yang menyatakan bahwa perusahaan lebih suka untuk menggunakan dana internal (laba ditahan) daripada dana eksternal (hutang dan ekuitas saham) untuk membiayai pengeluaran modalnya.

c. Pengujian Hipotesis (H3)

Berdasarkan tabel pengujian hipotesis mengenai pengaruh ukuran perusahaan (SIZE) terhadap struktur modal (DER) menunjukkan bahwa nilai signifikan sebesar $0,000<0,05$ dengan arah koefisien positif, maka dapat disimpulkan ukuran perusahaan (SIZE) berpengaruh positif dan signifikan terhadap sruktur modal (DER). Maka hipotesis 3 diterima.
Struktur modal merupakan kunci perbaikan produktivitas dan kinerja perusahaan. Peningkatan hutang diartikan oleh pihak luar tentang kemampuan perusahaan untuk membayar kewajiban dimasa yang akan datang atau adanya risiko bisnis yang rendah, hal tersebut akan direspon secara positif oleh pasar. Hasil ini sesuai dengan penelitian yang dilakukan Primantara \& Dewi (2016), Alvareza dan Topowijono (2017), Sari \& Haryanto (2013) dan Lasut, Rate, \& Raintung, (2018) yang menyatakan bahwa ukuran perusahaan berpengaruh pada struktur modal. Namun hasil penelitian ini tidak mendukung hasil penelitian Joni \& Lina (2010) yang menyatakan bahwa ukuran perusahaan tidak berpengaruh terhadap struktur modal.

\section{Uji Koefisien Determinasi $\left(\mathbf{R}^{2}\right)$}

Koefisien determinasi ini menunjukkan seberapa besar variabel bebas dapat menjelaskan variabel dependen yang dinyatakan dalam persen (\%).Pengujian koefisien determinasi dapat dilihat dari nilai $R$ - Squere sebagai berikut :nilai koefisien determinasi ditunjukkan dengan nilai $R$ - Squere sebesar 0,392. Hal ini dapat diartikan bahwa ukuran perusahaan (SIZE) dan profitabilitas (ROA) dapat menjelaskan pengaruhnya terhadap variabel struktur modal (DER) sebesar 39,2\%, sedangkan sisanya dapat dijelaskan oleh variabel lain diluar model penelitian ini.

\section{Kesimpulan}

a. Ukuran Perusahaan (SIZE) berpengaruh positif dan signifikan terhadap profitabilitas (ROA). Semakin besar Ukuran Perusahaan (SIZE), maka semakin meningkat profitabilitas (ROA).

b. Profitabilitas (ROA) berpengaruh positif dan signifikan terhadap struktur modal (DER). Semakin tinggi profitabilitas (ROA), maka semakin tinggi struktur modal (DER).

c. Ukuran perusahaan (SIZE) berpengaruh positif dan signifikan terhadap sruktur modal (DER). Semakin besar Ukuran perusahaan (SIZE) maka semakin meningkat struktur modal (DER).

\section{Ucapan Terima Kasih}

Peneliti mengucapkan terima kasih kepada pihak-pihak yang telah membantu selesainya penelitian ini dan kepada pihak pengelola Jurnal Akuntansi dan Pajak STIE AAS Solo yang telah berkenan menerbitkan artikel kami. 
6. Daftar Pustaka

Akhmadi, A., Rosyid, A., \& Handayani, F. (2018). Profitabilitas, Likuiditas, Rasio Pajak Dan Struktur Modal: Studi Hubungan Kausalitas Pada Perusahaan-Perusahaan Seb Sektor Perdagangan Besar Barang Produksi Yang Listing Di Bursa Efek Indonesia Periode 20102014. Jurnal Riset Akuntansi Terpadu, 11(2), 148-158.

https://doi.org/10.35448/jrat.v11i2.4253

Alvareza, A dan Topowijono. (2017). Analisis Pengaruh Ukuran Perusahaan, Profitabilitas, Dan Pertumbuhan Perusahaan Terhadap Struktur Modal (Studi Pada Perusahaan Food And Beverages YangTerdaftar Di Bei 20122015). Jurnal Adminstrasi Bisnis (JAB), 50 (4), September 2017, UB Malang.

Ambarwati, Gede Adi Yunitara, Ni Kadek Sinarwati. (2015). Pengaruh Modal Kerja, Likuiditas, Aktivitas dan Ukuran perusahaan terhadap Profitabilitas pada Perusahaan Manufaktur yang Terdaftar di Bursa Efek Indonesia. Jurnal Ilmiah Akuntansi, Vol.3,No.1, 2015.

Andayani, I. A. K. T., \& Suardana, K. A. (2018). Pengaruh Profitabilitas, Likuiditas, Pertumbuhan Penjualan, dan Struktur Aktiva Pada Struktur Modal. E-Jurnal Akuntansi, 24, 370.

https://doi.org/10.24843/eja.2018.v24.i01.p14

Armelia, S. (2016). Pengaruh Ukuran Perusahaan, Profitabilitas, Likuiditas dan Struktur Aktiva terhadap Struktur Modal Perusahaan Manufaktur Go Publik. Jom Fisip, 3(2), 1-13.

Brigham, Eugene F. dan Houston, Joel F. (2011). Dasar-dasar Manajemen Keuangan. Terjemahan. Edisi 10. Jakarta: Salemba Empat.
Dewiningrat, A. I., \& Mustanda, I. K. (2018). Pengaruh Likuiditas, Profitabilitas, Pertumbuhan Penjualan, dan Struktur Aset terhadap Struktur Modal. E-Jurnal Manajemen Universitas Udayana, 7(7), 3471-3501.

Joni, \& Lina. (2010). Analisis Faktor-faktor yang Mempengaruhi Struktur Modal. Jurnal Bisnis Dan Akuntansi, 12(2), 81-96.

Juliantika, N., \& Dewi, M. (2016). Pengaruh Profitabilitas, Ukuran Perusahaan, Likuiditas, Dan Risiko Bisnis Terhadap Struktur Modal Pada Perusahaan Property Dan Realestate. EJurnal Manajemen Universitas Udayana, 5(7), 4161-4192.

Lasut, S. J., Rate, P. Van, \& Raintung, M. C. (2018). Pengaruh Ukuran Perusahaan, Profitabilitas, Dan Likuiditas Terhadap Struktur Modal Pada Perusahaan Otomotif Yang Terdaftar Di Bursa Efek Indonesia Periode 2012-2015. Jurnal EMBA, 6(1), 11-21.

Primantara, A., \& Dewi, M. (2016). Pengaruh Likuiditas, Profitabilitas, Risiko Bisnis, Ukuran Perusahaan, Dan Pajak Terhadap Struktur Modal. E-Jurnal Manajemen Universitas Udayana, 5(5), 2696-2726.

Putra, PSR. (2009). Manajemen Keuangan dan Akutansi Untuk Eksekutif Perusahaan, PT. Raja Grafindo Persada, Jakarta.

Sari, D. V, \& Haryanto, A. M. (2013). Pengaruh Profitabilitas, Pertumbuhan Aset, Ukuran Perusahaan, Struktur Aktiva Dan Likuiditas Terhadap Struktur Modal Pada Perusahaan Manufaktur Di Bursa Efek Indonesia Tahun 2008 - 2010. Diponegoro Journal of Management, 2(3), 1-11.

Wimelda dan Marlinah. (2013). Variabel-Variabel Yang Mempengaruhi Struktur Modal Pada Perusahaan Public Sektor Non-Keuangan. Media Bisnis, 5(3), 200-213. 